\title{
Imágenes y ermitaños. Un ciclo hierofánico ignorado por la Historiografía/
}

\author{
Images and Hermits. An hierophanic Cycle ignored \\ by the Historiography
}

Antonio Rubial García

UNAM, México DF

Hasta el momento, la historiografía sobre las apariciones milagrosas en el mundo hispanoamericano ha privilegiado la participación de los indígenas en dicho proceso y, así, ha olvidado a otros importantes actores en él. A través del análisis de seis casos de santuarios novohispanos, este artículo muestra que los ermitaños constituyeron otra presencia casi tan importante como aquella, tanto en la literatura aparicionista como en la formación de esos centros de peregrinación.

PALABRAS CLAVE: Imágenes milagrosas; Ermitaños; Santuarios de peregrinación.

So far, historiography on miraculous apparitions in Colonial Latin America has privileged indigenous participation in such process and, thus, has forgotten other important actors in it. Through the analysis of six cases of Novohispanic sanctuaries, this article shows that hermit's presence was almost as important as the indigenous one, both in literature on apparitons and the formation of those centers of pilgrimage.

KEYwords: Miraculous images; Hermits; pilgrimage shrines. 
Con las nuevas corrientes historiográficas interesadas en la historia cultural, la segunda mitad del siglo XX vio aparecer un inusitado interés por los temas religiosos, temas considerados hasta entonces de escasa importancia por los historiadores laicos. Una de las cuestiones que ha recibido la atención de los especialistas más recientemente es la de las imágenes milagrosas y su culto. Después de los estudios pioneros de William Christian Jr. sobre la Península Ibérica, ${ }^{1}$ varios investigadores se han dedicado al rico y variado fenómeno hierofánico desarrollado en América durante el periodo virreinal: Jaime Cuadriello, Pierre Ragon y William Taylor, entre otros, han desarrollado interesantes aspectos sobre las imágenes novohispanas, su entorno, su promoción y su culto. ${ }^{2}$

Para el virreinato del Perú son notables los trabajos pioneros de Teresa Gisbert y Juan Carlos Estenssoro. ${ }^{3}$ En general, tanto los estudios novohispanos como los peruanos han atendido al hecho incontrovertible de que estas hierofanías, y la literatura que generaron, estaban dirigidas a consolidar una evangelización que había sido insuficiente y que se gestaba en ámbitos donde existían cultos a divinidades indígenas. La presencia de un indio vidente en dichas manifestaciones y el éxito inusitado de una de ellas, la de la Virgen de Guadalupe, dirigió las investigaciones hacia ese tipo de ciclos, a los cuales se les comparó con el llamado "ciclo de los pastores" de la literatura aparicionista española.

Así, el interés generalizado por los temas indígenas, reforzado por las perspectivas antropológicas, determinó que la mayoría de los trabajos relacionados con estas materias se centraran en aquellas apariciones donde la

1 Ver, por ejemplo, sus obras: Apariciones milagrosas en Castilla y Cataluña. Siglos XIVXVI, Madrid, Nerea, 1990; Religiosidad local en la España de Felipe II, Madrid, Nerea, 1991.

2 Jaime Cuadriello ha dedicado numerosos estudios a las apariciones, sobre todo la de la Virgen de Guadalupe. Es por ejemplo de destacarse "Tierra de prodigios. La ventura como destino" en Los pinceles de la Historia. El origen del reino de la Nueva España (1680-1750), México, Museo Nacional de Arte, 1999, pp.180-227; Las glorias de la República de Tlaxcala o la conciencia como imagen sublime. México, Instituto de Investigaciones Estéticas, UNAM-Museo Nacional de Arte, 2004. Pierre Ragon: Les saints et les images du Mexique: XVIe-XVIIIe siecle, Paris, L'Harmattan, 2003. Ver también su artículo citado aquí más adelante sobre Sacromonte. William Taylor ha escrito varios artículos sobre la Virgen de Guadalupe, por ejemplo: "Mexico's Virgin of Guadalupe in the Seventeenth Century: Hagiography and Beyond", Greer Allan and Bilinkoff Jodi (eds.): Colonial Saints. Discovering the Holy in the Americas, New York, Routledge, 2003, pp. 277-298. Ver también su artículo citado más adelante sobre el Cristo de Ixmiquilpan.

3 Gisbert, Teresa: Iconografía y mitos andinos en el arte, La Paz, Gisbert Editores, 1980; El paraíso de los pájaros parlantes. La imagen del otro en la cultura andina, La Paz, Plural, 2001. Véase también el capítulo de la Virgen de Copacabana de Juan Carlos Estenssoro en: Del paganismo a la santidad, Lima, Pontificia Universidad Católica del Perú, 2004.. 
realidad indígena era más ostensible. Sin embargo, ésta no fue la única presencia ni en la literatura (que yo he denominado "hierofánica"), ni en las referencias al fenómeno aparicionista en otras fuentes. ${ }^{4}$ Por principio de cuentas, no todas las imágenes de los santuarios novohispanos nacieron de un fenómeno de sustitución sobre un centro de peregrinación prehispánico; algunas surgieron en ámbitos urbanos españoles como instrumentos de conformación de las identidades locales y no forjaron propiamente un santuario autónomo, sino que estaban situadas en capillas anexas a templos. Por otro lado, los indios no fueron los únicos personajes vinculados con las narraciones de ese género de prodigios, sino que personajes diversos (monjas, sacerdotes, españoles, mulatos y mestizos) aparecen también como testigos de tales hechos. Entre todos ellos existe sin embargo un prototipo, tan importante como el de los indios, cuya presencia puede constituir un "ciclo" modélico y que ha sido un fenómeno ignorado, precisamente por la omnipresencia de los intereses indigenistas: el ciclo de los ermitaños.

Las apariciones milagrosas a ermitaños, o asociadas con ellas, no son extrañas en los procesos aparicionistas europeos. En Cataluña, según William Christian Jr., abundan las referencias a espacios sagrados relacionados con ermitaños y hasta el mismo Montserrat, con mucha probabilidad, fue al principio un conjunto de ermitas antes de que ahí hubiera una Virgen. ${ }^{5}$ El anacoreta, al vencer la tentación con su ascetismo, restituía a la naturaleza su armonía original (de ahí que pudiera convivir pacíficamente con los animales salvajes) y podía así convertirse en un intermediario ideal entre los hombres y la divinidad. Por otro lado, debido a su contacto con el espacio natural y a su alejamiento del mundo urbano, el eremita era un restaurador idóneo del paraíso y de la perfección primigenia, revertía lo que había sucedido en el Edén, donde Adán fue vencido por el demonio, creando las condiciones ideales de un espacio purificado para las manifestaciones celestiales.

Éstas, de acuerdo a la clasificación de William Christian Jr., podían darse de tres formas: apariciones, signos y hallazgos. En la primera, los personajes celestes se muestran en carne y hueso, hablan, caminan y se relacionan con el vidente dejándole una imagen como prueba de la aparición; en la segunda, la revelación se realiza por medio de señales que suce-

4 Antonio Rubial: "Invención de prodigios. La literatura hierofánica novohispana", Historias, Revista de la dirección de estudios históricos del INAH, v. 69, México, 2008, pp. 121-132.

5 Christian: Apariciones, p. 152. 
den sobre el cuerpo de la imagen (llanto, sudoración, efusión de sangre o reconstitución milagrosa); en la tercera, gracias a un sueño o visión, la imagen (tan antigua que se remonta a los tiempos apostólicos) es objeto de un hallazgo. ${ }^{6}$ Los dos primeros casos pueden ser observados en Nueva España en el "ciclo de los ermitaños"; no obstante también existen ejemplos del tercer tipo en Nueva España, como la Virgen de los Remedios, pero esta imagen se apareció a un indio y por tanto se sale de nuestro objetivo.

Antes de entrar en materia debo hacer dos aclaraciones. Por un lado, la actividad eremítica desde el cristianismo primitivo estuvo claramente definida como un ideal de ascetismo en la soledad (el yermo), pero desde el siglo XI el tópico literario se desvinculó de los anacoretas reales, itinerantes, rebeldes y reacios a sujetarse al dominio eclesiástico. Por ello, desde el siglo posterior convivieron dos géneros de vida eremítica, uno que estaba avalado por la Iglesia pues proponía la experiencia de la soledad dentro de una orden religiosa institucional, y otro, visto siempre con desconfianza, que buscaba los lugares apartados de manera individual. Ambos modos de vida "retirada" del mundo se dieron en Nueva España: la primera en las órdenes franciscana, agustiniana y carmelitana y la segunda en numerosos individuos que, en no pocas ocasiones, fueron juzgados por el tribunal del Santo Oficio de la Inquisición. En los fenómenos aparicionistas novohispanos se presentan los dos tipos de ermitaños, aunque, por razones obvias, predomina el primero. ${ }^{7}$

Por otro lado, en los procesos que voy a estudiar en este ensayo, la presencia del ermitaño no siempre está vinculada con la aparición misma de la imagen o con su hallazgo, sino más bien con la evolución del santuario y su éxito. Por ello es pertinente hacer una distinción entre los dos momentos de la evolución en todo proceso aparicionista: uno, el del surgimiento del fenómeno en un ámbito de oralidad caracterizado por una gran credulidad hacia lo milagroso y por una narratividad que mezcla elementos de diferentes procedencias, en la cual cada emisor agrega a la versión "original" sus propios retazos de memoria; el otro, el de la fijación por escrito de esa tradición varias décadas después, en el cual se transforma la pluralidad narrativa oral en una versión única, "canónica", que consolida una historia oficial y, con ella, todo el andamiaje sociocultural que constituye

6 Ibidem, pp. 19-20.

7 Antonio Rubial: Profetisas y solitarios, Espacios y mensajes de una religión dirigida por ermitaños y beatas laicos en las ciudades de Nueva España, México, Fondo de Cultura Económica (FCE)-Facultad de Filosofía y Letras, UNAM, 2006. 
un santuario. ${ }^{8}$ En general, el éxito de casi todos los santuarios está basado en la difusión oral y en la escritura de un texto fundante, aunque hay excepciones, como veremos.

\section{Dos santuarios de sustitución, dos ermitaños de excepción. Amecameca y Chalma}

La más notable de estas excepciones dentro del ciclo que nos ocupa y que es una de las pocas que no posee un texto canónico virreinal, la constituye el santuario del Señor de Amecameca o del Sacromonte, asociado con la figura señera que consagraron fray Toribio de Motolinía y fray Francisco Jiménez: el padre fray Martín de Valencia, quien venía a la cabeza de los primeros doce franciscanos llegados a Nueva España en 1524. Este personaje, según sus biógrafos, mostró una fuerte inclinación al eremitismo desde su estancia en España y en los dos últimos años de su vida, de los diez que vivió en Nueva España, habitó largas temporadas en la cueva del monte Amaqueme cercano a Amecameca, frente al Iztaccíhuatl, donde se retiraba a hacer vida de anacoreta en una ermita dedicada a Santo Tomás apóstol y en la que tuvo visiones de San Antonio y San Francisco. ${ }^{9}$

Alrededor de 1534 fray Martín murió en el vecino pueblo de Tlalmanalco, pero la cueva donde había pasado parte de su vida se volvió un centro de culto pues, además, era para los indios un lugar sagrado en el cual existía un santuario a Tláloc, el dios de la lluvia, y a Chalchiuhtlicue, la diosa del agua. ${ }^{10}$ En 1537 los dominicos llegaron a la zona para suplir a los franciscanos, lo cual incidió en el equilibrio político de ella. El cronista Domingo de San Antón Chimalpáhin parece indicar en su Séptima Relación que en Amecameca había dos grupos rivales que cifraban su poder en la presencia de los franciscanos o de los dominicos en el poblado:

8 Para ampliar estos aspectos se puede ver el libro de Víctor y Edith Turner: Image and Pilgrimage in Christian Culture, New York, Columbia University Press, 1978.

9 Toribio de Motolinía: Historia de los indios de la Nueva España, relación de los ritos antiguos, idolatrías y sacrificios de los indios de la Nueva España y de la maravillosa conversión que Dios en ellos ha obrado, edición de Edmundo O’Gorman, México, Porrúa, (Colección Sepan Cuántos...,129), 1969, Trat. III, cap. 2, pp. 120-124. Ver también la biografía que hizo su hermano de hábito fray Francisco Ximénez (publicada con un estudio de Pedro Ángeles en el apéndice a Antonio Rubial): La hermana pobreza. El franciscanismo: de la Edad Media a la evangelización novohispana, México, Facultad de Filosofía y Letras, UNAM, 1996, pp. 211-261.

10 Pierre Ragon: "La colonización de lo sagrado: la historia del Sacromonte de Amecameca." Relaciones, Estudios de Historia y Sociedad, XIX-75, Zamora, Mich., verano de 1998, pp. 281-300. 
uno encabezado por el antiguo señor Tomás de San Martín Quetzalmaza, protector del padre Valencia y quien le permitió asentarse en el cerro sagrado; otro dirigido por su hermano, Juan de Sandoval Tecuanxayaca, que trajo a los dominicos y apoyó la construcción de su convento en 1547; el mismo autor deja entrever, además, un cierto descontento de los amaquemecas contra los de Tlalmanalco por que no les avisaron que habían enterrado el cuerpo del fraile. ${ }^{11}$

Alrededor de 1564 el cadáver de fray Martín, que según el cronista fray Jerónimo de Mendieta estaba incorrupto, desapareció misteriosamente de su tumba en el convento franciscano de ese pueblo y nunca apareció, a pesar de que en 1580 se publicaron unas letras apostólicas con "graves censuras" contra quienes habían sustraído la reliquia. ${ }^{12}$ Tres años después, en 1583, un grupo de indios de Amecameca entregaron a fray Juan de Páez, vicario dominico de ese convento, algunas reliquias (cilicios, una túnica y dos casullas según Mendieta, una casulla confeccionada con pelo de conejo y un misal según Chimalpáhin) que, según decían, habían pertenecido a fray Martín de Valencia. ${ }^{13}$ La misteriosa desaparición del cadáver del ermitaño y la entrega del cilicio y de los hábitos del venerable al padre Páez, encajan perfectamente en este ambiente de pugnas y de luchas entre pueblos y caciques por obtener la preeminencia y el control del cerro sagrado. ${ }^{14}$ Los frailes dominicos, por su parte, tenían también sus razones para promover el culto de fray Martín, además de obtener el apoyo de las autoridades indígenas locales: suplantar el santuario dedicado a los dioses del agua por un centro cristiano.

Los dominicos, según Mendieta, mostraban a quien lo pidiera las reliquias que se encontraban en la sacristía de Amecameca e incluso regalaban

11 Este cronista señala que Sandoval remarcaba el contraste entre sus frailes dominicos "con sus hábitos limpios y pies calzados" y los franciscanos de su hermano "con sus andrajos sucios y sus pies agrietados". Domingo de San Antón Muñoz Chimalpáhin: "Séptima Relación" en Las ocho relaciones y el Memorial de Colhuacan, 2 vols., paleografía y traducción Rafael Tena, México, CONACULTA, 1998, vol. II, p. 195. El mismo autor señala las diferencias entre los de Amecameca y Tlalmanalco alrededor del cuerpo del venerable Valencia en Ibidem, vol. II, pp. 189-191.

12 Jerónimo de Mendieta: Historia Eclesiástica Indiana, 2 vols., edición de Antonio Rubial, México, Consejo Nacional para la Cultura y las Artes (Colección Cien de México), 1997, Lib. V, cap. 13; vol. II, pp. 295-297.

13 Ibidem, Lib. V, cap. 16; vol. II, pp. 304-305. Chimalpáhin: Séptima Relación, vol. II, p. 189. Este autor es el único que da como fecha de esta entrega 1583.

14 En 1570 fray Juan de Páez, entonces vicario en Tetela, acompañó a José del Castillo Ecaxoxouhqui, tlatoani de Tenango e hijo único de Tomás de San Martín Quetzalmaza, para que fuera gobernador de Amecameca. La situación política había cambiado para la segunda mitad del siglo y los dominicos apoyaban ahora a la otra facción. Chimalpáhin: Séptima Relación, vol. II, p. 237. 
trozos de la túnica, hasta que finalmente decidieron ponerlas en la cueva en una cajita cubierta con una red de hierro, a los pies de un altar en el que se veneraba una escultura de Cristo muerto que, según el cronista fray Agustín Dávila Padilla, "se desciende de la cruz y se visita y muestra" en dicha capilla. ${ }^{15}$ Para la orden, la promoción de este santuario era de suma importancia pues el convento de Amecameca se había convertido en paso obligado para su red de misiones en el valle de Amilpas y la Mixteca.

Sobre la fecha de la colocación de esa escultura existen diferencias entre los cronistas. Chimalpáhin asevera categóricamente que el 20 de junio de 1583 se asentó en la cueva que está sobre el cerro Amaqueme "una imagen de Cristo yacente en el sepulcro", en el sitio donde había hecho penitencia fray Martín de Valencia; esto se hizo a instancias del vicario fray Juan de Páez, del gobernador de Panoaya Felipe Páez de Mendoza y de los alcaldes Juan de la Cruz y Bartolomé de Santiago. ${ }^{16}$ En cambio fray Agustín Dávila Padilla señala que en 1579 el general de la armada don Antonio Manrique había donado para la veneración del Santo Cristo una lámpara de plata. ${ }^{17}$ Es muy probable que haya un error en la fecha, pero cabría la posibilidad de que la colocación de la imagen se hubiera dado desde el primer vicariato de fray Juan de Páez, alrededor de 1575 según Chimalpáhin. ${ }^{18}$ Pero sea que la imagen haya existido antes de las reliquias en la cueva, o que su colocación haya coincidido con el descubrimiento de los objetos de fray Martín, el hecho es que alrededor de 1580 fray Juan de Páez ya había fundado en Amecameca la cofradía del Descendimiento y Sepulcro de Cristo, y se había promovido una procesión del Santo Entierro para organizar las suntuosas representaciones de Semana Santa que los dominicos comenzaban a introducir en sus conventos. ${ }^{19}$

Para 1588 el santuario ya tenía vida propia y en nada lo afectó que ese año fray Juan de Páez fuera expulsado de la vicaría, junto con su protegido el cacique Esteban de la Cruz Mendoza, por Juan Bautista de Avendaño y "unos macehuales". ${ }^{20}$ Las nuevas fuerzas que gobernaban Amecameca

15 Agustín Dávila Padilla: Historia de la fundación y discurso de la provincia de Santiago de México de la orden de predicadores por las vidas de sus varones insignes y casos notables de Nueva España, Madrid, Pedro Madrigal, 1596. Lib. II, cap. 65, p. 705.

16 Chimalpáhin: Séptima Relación..., vol. II, pp. 255-257.

17 Dávila Padilla: Historia..., Lib. II, cap. 65, p. 706.

18 Ese año el vicario fray Juan de Páez instaló a don Esteban de la Cruz Mendoza como gobernador de Amecameca. Chimalpáhin, Séptima Relación, vol. II, p. 243.

19 Dávila Padilla: Historia..., Lib. II, cap. 65, p. 705.

20 Chimalpáhin: Séptima Relación, vol. II, p. 263. 
desplazaban a los antiguos linajes y comenzaban a controlar tanto la república de indios (el Cabildo) como el santuario, que era el símbolo de identidad del pueblo. Fray Antonio de Ciudad Real, que visitó el lugar en 1587, cuenta que: "aunque la cueva tiene sus puertas y buena llave con que se cierra, hay de continuo indios por guardas en otra cuevezuela allí cerca; tañen a sus horas una campana que tienen en lo alto del cerro, cuando abajo tañen en el monasterio". ${ }^{21}$ Un año antes del "golpe de estado" ya los macehuales se hacían cargo del espacio sagrado en el que habían colocado puerta con cerrojo. El santuario, por lo tanto, estaba cerrado al público la mayor parte del tiempo, salvo los viernes que se celebraba una misa, y para poder visitarlo fuera de ese tiempo había que buscar al vicario del convento. El viajero franciscano señala que:

Cuando se han de mostrar las reliquias, sube el vicario del convento con la compañía que se ofrece, tocan la campana y júntase gente, encienden algunos cirios, además de una lámpara de plata que se cuelga de la peña en mitad de la ermita, y el vicario, vestido de sobrepelliz y estola, abre la caja, y hecha oración al Cristo le inciensa, y después inciensa las reliquias y muéstralas a los circunstantes, todo con tanta devoción que es para alabar al Señor en sus santos.22

A pesar de estas limitaciones, para fines del siglo XVI la imagen, reforzada por la presencia de las reliquias, atraía a numerosos devotos que, de acuerdo al cronista dominico Dávila y al viajero franciscano Ciudad Real, eran españoles e indígenas, venían desde Chalco y otras regiones y dejaban ricas limosnas..$^{23}$ El nuevo santuario se convirtió en breve, por su localización en un camino muy transitado que comunicaba Chalco con la zona de Amilpas y el sureste, en uno de los centros de peregrinación más importantes de Nueva España. Al parecer su control se mantuvo bajo la comunidad indígena de Amecameca, por lo menos hasta el siglo XVIII.

En 1687 su culto estaba al cuidado de la cofradía del Santo Entierro que ese año se unió a la del Santísimo Sacramento con la ratificación del arzobispo Aguiar y Seijas, después de su visita pastoral al lugar. ${ }^{24} \mathrm{~A}$ fines del siglo XVIII el episcopado seguía promoviendo el culto pues en 1794,

21 Antonio de Ciudad Real: Tratado curioso y docto de las grandezas de la Nueva España, 2 vols., edición de Josefina García y Víctor Castillo, México, Instituto de Investigaciones Históricas, UNAM (Serie de historiadores y cronistas de Indias, 6), 1976, vol. II, p. 222.

22 Ibidem.

23 Dávila Padilla: Historia..., Lib. II, cap. 65, p. 705.

24 Rigel García: De la cueva al sacromonte: cuerpos y territorios. El santo Entierro del Amaqueme, Facultad de Filosofía y Letras, UNAM., Tesis de Maestría en Historia del Arte inédita México DF, 2008, p. 30. 
los obispos de Puebla y Sonora concedieron indulgencias a aquellos peregrinos de sus diócesis que visitaran el santuario. ${ }^{25}$ Por esas fechas concluía el largo curato de Lino Nepomuceno Gómez, quien había tomado a su cargo la parroquia de Amecameca en 1777, a tres años de haber sido dejada por los dominicos por la secularización. A lo largo de más de tres lustros este sacerdote había realizado importantes obras en el santuario y en el pueblo (arcos, calzadas, vía crucis, edificación fuera de la cueva, decoración con temas eremíticos, como Santa María Egipciaca y San Simeón el Estilita) convirtiéndolo en un Sacromonte, palabra que comenzó a usarse desde entonces para denominar al santuario. Detrás de estas obras no sólo estaba la necesidad de consolidar la presencia del clero secular recién instaurado, sino también meter en orden a las autoridades "indígenas" y arrebatarles el control del lugar, cosa que ya había intentado el cura anterior al establecer un mayordomo autónomo que cobrara las limosnas del santuario y que fuera independiente de la cofradía. El conflicto se manifestó primero entre el cura y el cacique local, Luís Páez de Mendoza, y después con el pueblo, que se quejó por la elevación de los costos de los servicios parroquiales para remodelar el santuario. Para Rigel García, que ha estudiado este fenómeno, la intervención en el cerro y la cueva por parte del cura Gómez se insertaba en el programa episcopal de control sobre las devociones populares; con esos trabajos, el viejo santuario indígena de Amaqueme, controlado por la comunidad hasta entonces y conservado en su entorno natural, pasaba a convertirse en un Sacromonte con edificaciones y servicios y bajo el cuidado y la explotación del clero secular. ${ }^{26}$

En el proceso cultual del Cristo de Amecameca, las primeras narraciones insertas en crónicas franciscanas o dominicas habían puesto un mayor interés en las reliquias de un ermitaño, quedando la imagen del Cristo en un segundo plano. Quizás por ello no se desarrolló una narración de actividades milagrosas alrededor de ella en los siglos XVII y XVIII, a pesar de que el santuario atraía a numerosos peregrinos. Esa dependencia de la imagen respecto al ermitaño puede verse en la inscripción que contenía una estampa del Santo Entierro de Sacromonte que circulaba a fines del XVIII (seguramente formando parte de la promoción del cura Gómez) y que fue recogida por la Inquisición. En ella se decía: "La imagen del Señor de Meca que se venera en la cueva donde se refiere habérsele aparecido al V.P.F. Martín de

25 Fortino Hipólito Vera: El santuario de Sacromonte. O lo que se ha escrito sobre él desde el siglo XVI hasta el presente, Amecameca, Tipografía del Colegio Católico, 1881, pp. 18-19.

26 García: De la cueva al sacromonte..., pp. 84-90. 
Valencia (1782)". ${ }^{27}$ Por lo visto, ante el silencio de una tradición canónica, circularon popularmente versiones milagrosas como ésta, que se insertaba en las narraciones sacralizadas por las crónicas mendicantes.

Esta ausencia se hizo notable curiosamente hasta el XIX, siglo en el cual, según los testimonios recogidos por Fortino Hipólito Vera, la imagen alcanzó una difusión inusitada gracias a la promoción de los párrocos seculares de Amecameca. Este autor incluso menciona una narración, recogida según dice por un autor contemporáneo, en la cual se decía que la imagen había llegado a la cueva sobre el lomo de una mula, desviada de su recua y estacionada en el lugar sagrado, con lo cual había mostrado la voluntad divina de resaltar lo excepcional del Santo Cristo. A pesar de que el autor alega la antigüedad de esta tradición tardía, no existe ningún texto virreinal que la avale, aunque su misma mención nos habla de la persistencia de modelos medievales (animales que portan imágenes milagrosas) en un periodo tan tardío como el siglo XIX.

Una situación distinta se dio en el santuario prehispánico de Chalma, donde una versión oficial del milagro comenzó a gestarse en el siglo XVII y se plasmó en un texto impreso. Desde el siglo XVI los agustinos promovieron el culto de la imagen de un Cristo crucificado en una cueva en la que se veneraba a Oxtotéotl, una advocación de Tezcatlipoca, pero donde el control indígena sobre la imagen, a diferencia de Sacromonte, desapareció muy pronto. Según la tradición recogida por Francisco de Florencia a fines del siglo XVII, fray Nicolás de Perea y fray Sebastián de Tolentino habían recibido noticias en 1539 sobre los cultos que se realizaban en una de las cuevas de la región denominada Chalma, cercana al convento de Ocuila recién fundado y donde ellos residían. Sin embargo, temerosos de la reacción de los idólatras decidieron regresar al día siguiente con refuerzos y, dispuestos a destruir el objeto que habían encontrado previamente, descubrieron un prodigio: el ídolo estaba hecho pedazos en el piso, la cueva se hallaba sembrada de flores y en el altar un crucifijo había suplantado milagrosamente al ídolo-demonio. El milagro recordaba al jesuita el pasaje bíblico del dios filisteo Dagón destruido con la presencia del Arca de la Alianza (I Sam. 5, 14).

Extrañamente fray Juan de Grijalva, el cronista de la orden, no menciona en ninguna parte de su texto el culto al Cristo de Chalma, ni en la

27 Archivo General de la Nación México (en adelante AGNM), Inquisición, v. 1360, exp. 1, año 1795, f . 357. Catálogo de ilustraciones, num. 4900. 
vida de fray Nicolás de Perea hace alusión a la aparición ni a su labor misionera en la zona de Malinalco, lo que significa que en 1624 (fecha en que se imprimió la crónica) no existía aún una narración del "milagro". ${ }^{28}$

El jesuita Florencia, única fuente canónica del prodigio, señala que en 1623 llegó al santuario Bartolomé de Torres, un ex arriero mestizo de Huejotzingo a quien un revés de la fortuna había llevado a entregarse a prácticas ascéticas y a servir a los fieles que visitaban la ermita del Santo Cristo con consejos y curaciones. Con tal fama de taumaturgo, el eremita mestizo comenzó a atraer hacia el santuario gran afluencia de enfermos y suplicantes. El fenómeno llamó la atención de los religiosos, quienes en 1629, según Florencia, por mano de fray Juan de Grijalva, entonces prior de Malinalco, dieron al curandero el hábito agustino. ${ }^{29}$

Es claro que con este acto la orden se beneficiaba del prestigio del santón y continuaba ejerciendo el control sobre el santuario. El mestizo Bartolomé cumplía además las funciones de intermediación que necesitaban los frailes para atraer a las comunidades indígenas; el "chamán cristiano" convertido en religioso no sólo aseguraba la ortodoxia de la predicación, podría también suplantar con su "magia" a los hechiceros indios ${ }^{30} \mathrm{El}$ hermano lego fray Bartolomé de Jesús María, como fue llamado el ermitaño al entrar a la congregación, recibió algún tiempo después como ayudante a un muchacho mestizo de ocho años, donado por sus padres a la ermita, que recibiría también en el futuro el hábito agustino y el nombre de fray Juan de San José. El nuevo ermitaño, según Florencia, continuaría con la tradición de su maestro y se dedicaría a difundir su vida y los prodigios de la imagen. Cuando fray Bartolomé murió en 1658 su cuerpo fue enterrado en la cueva a los pies del Santo Cristo. De nuevo acá, como en Sacromonte, la devoción a la imagen se reforzaba con la presencia de las reliquias de un ermitaño y con la difusión que de su vida y milagros hizo su discípulo. Es muy probable que la leyenda hierofánica de la cueva haya sido inspirada

28 Juan de Grijalva: Crónica de la orden de N.P.S. Agustín en las provincias de Nueva España. Introducción y apéndices de León Nicolás, México, Porrúa, 1985, Lib. IV, cap. 24, pp. 442-444. Nicolás de Perea había llegado a México en 1539 y dos años después fue enviado a una misión a Filipinas con Ruy López de Villalobos.

29 Francisco de Florencia: Descripción histórica y moral del yermo de San Miguel de las Cuevas en el Reino de la Nueva España e invención de la milagrosa imagen de Christo Nuestro Señor crucificado que se venera en ellas. Con un breve compendio de la admirable vida del venerable anacoreta fray Bartolomé de Jesús María y algunas noticias del santo fray Juan de San Joseph, su compañero, Cádiz, Imprenta de la Compañía de Jesús, Cristóbal de Requena, 1689.

30 Antonio Rubial: “Tebaidas en el paraíso. Los ermitaños de Nueva España”, en Historia Mexicana, XLIV-3 (175), México, enero-marzo de 1995, pp. 355-383. 
por los ermitaños mestizos de Chalma a partir de entonces, lo que explicaría el silencio de Grijalva en 1624.

El culto al Santo Cristo de Chalma tuvo una enorme difusión territorial a lo largo del siglo XVII y, junto con los viajes promocionales de los ermitaños viajeros, influyó en ello la gran aceptación de la imagen entre los indios otomíes, quienes desde Acámbaro llegaban todos los años al santuario. Este grupo tuvo desde la segunda mitad del siglo XVI un importante papel en la colonización de las tierras del Bajío y en la penetración hacia la zona chichimeca del Tunal Grande (San Luís Potosí, Guadalcázar etc.) hacia donde llevaron algunas de las devociones del centro como la del Señor de Chalma. ${ }^{31}$

El último paso del proceso se dio a fines del siglo XVII. En 1683 la vida y milagros del ermitaño Bartolomé de Jesús María estaban ya tan difundidos que el arzobispo de México Francisco de Aguiar y Seijas permitió al oidor Juan de Valdés y a fray José Sicardo realizar las informaciones sobre la vida de tan ejemplar varón con el fin de iniciar su proceso de beatificación. ${ }^{32}$ En diciembre de 1684 el mismo prelado hizo una visita al santuario de Chalma y pidió que se abriera la tumba de la cueva donde se encontraba enterrado el ermitaño. La sorpresa fue grande al encontrar el cuerpo de Bartolomé incorrupto, símbolo inconfundible de santidad. ${ }^{33} \mathrm{Al}$ año siguiente los prebendados Alonso Alberto de Velasco y Francisco Romero fueron enviados por el arzobispo para reconocer la sepultura y a levantar nuevas informaciones. ${ }^{34}$

En tanto se iniciaban los trámites para la beatificación, el santuario de Chalma comenzaba a sufrir una serie de cambios por mano de fray Diego Velázquez de la Cadena. Este fraile, hermano del secretario de Gobernación y Guerra, comenzaba a afianzar su poder sobre la provincia agustina de México y necesitaba crear una imagen pública positiva que acabara con las fundadas acusaciones de corrupción que contra él se hacían. Para tal fin mandó crear dos comunidades cenobíticas de acuerdo con el espíritu de la orden, que recomendaba tener casas de recolección en cada provincia. Una

31 Juan Carlos Ruiz Guadalajara: Dolores antes de la independencia, 2 vols., México, El Colegio de Michoacán-El Colegio de San Luis-CIESAS, 2004, vol. II, pp. 400-401.

32 José Sicardo: Interrogatorio de la vida y virtudes del Venerable hermano fray Bartolomé de Jesús María, Natural de Xalapa. Religioso lego del Orden de Nuestro Padre Sant Agustin..., México, Imprenta de Juan de Ribera, 1683.

33 Antonio de Robles: Diario de sucesos notables, 3 vols., México, Porrúa, 1972, vol. II, p. 86.

34 Joaquín Sardo: Relación histórica y moral de la portentosa imagen de Nuestro Señor Jesucristo Crucificado aparecida en una de las cuevas de San Miguel de Chalma, México, Casa de Arizpe, 1810, Lib. II, cap. XXII, p. 319. 
de ellas, en el convento de Culhuacán, tuvo una vida efímera y trasladada después a Atlixco, finalmente desapareció. La otra, creada en Chalma, tuvo en cambio un gran éxito. ${ }^{35}$ Para lograr su cometido, el padre De la Cadena aprovechó un terraplén en el santuario que ya había iniciado fray Juan de San Joseph, y sobre él inició la construcción de un soberbio convento y de un templo al que mandó trasladar la imagen del Santo Cristo desde la cueva donde estaba en 1683. Un acta notarial enviada a Madrid daba noticia al rey de las obras realizadas y anunciaba a fray Diego como restaurador del espíritu eremítico en la provincia de México. ${ }^{36}$ Con ello el religioso no sólo consiguió prestigio personal, la provincia también recuperaba el control sobre la ermita, control que había perdido a pesar de existir ahí un lego agustino.

La fundación de la casa de recolección de Chalma convertía al último reducto de los ermitaños autónomos en una comunidad de frailes asimilada y controlada por la institución. Por otro lado, al separar la imagen de la tumba del ermitaño, que se quedó en la cueva, se rompía con la vinculación que durante seis décadas había asimilado cueva, Cristo y reliquias en un solo espacio simbólico. El proceso se había iniciado desde 1680; ese año, cuenta Antonio de Robles, el miércoles 14 de febrero, "trajo a México el provincial de San Agustín al lego de Chalma para mortificarlo un poco", ${ }^{37}$ La provincia agustina ya no veía con buenos ojos a fray Juan, ese fraile ermitaño mestizo que vivía muy a su aire y con una relativa autonomía. Al trasladarlo al convento de México, el prelado hacía desaparecer la presencia de un personaje popular en Chalma y ponía las bases para la fundación del cenobio institucional que crearía el padre de la Cadena. En ese sentido debe también entenderse que el peninsular fray José Sicardo, enemigo declarado del padre de la Cadena, imprimiera en 1683 las informaciones para abrir la causa de beatificación del ermitaño fray Bartolomé y que fuera el Cabildo de la ciudad de México, y no la provincia agustina, la instancia que iniciara los trámites en Roma. ${ }^{38}$ Con fray Diego de la Cadena los ermitaños se desvinculaban del santuario, que se convertiría a partir de entonces en un centro institucional controlado absolutamente por la provincia del Santísimo Nombre de Jesús.

35 Sobre este personaje ver Antonio Rubial: "Fray Diego Velásquez de la Cadena, un eclesiástico cortesano en la Nueva España de fines del siglo XVII", Anuario de Estudios Americanos. XLVI, Sevilla, 1989, pp. 173-194.

36 Testimonio público a petición de fray Diego de la Cadena, Chalma, 6 de marzo de 1684, Archivo General de Indias (en adelante AGI), México, 708.

37 Robles: Diario..., vol. II, p. 276.

38 Sicardo: Interrogatorio..., sin página. 
En 1684 fray Diego era electo provincial de los agustinos de México y en el tiempo de su provincialato (1684-1687) promovió seguramente que el jesuita Francisco de Florencia escribiera una narración de la leyenda del Santo Cristo. En 1689, año en que moría fray Juan de San Joseph, este jesuita criollo publicaba en Cádiz esa obra bajo el titulo Descripción histórica y moral del yermo de San Miguel de las Cuevas. ${ }^{39}$ En ella, Florencia incluyó las vidas y obras del taumaturgo eremita mestizo fray Bartolomé de Jesús María y de su discípulo y hacía constantes paralelismos entre el primero y los santos Pablo el ermitaño, Antonio, Macario e Hilarión. Incluso llegó a insinuar que su biografiado los había sobrepasado, aseveraba asimismo que los portentos obrados por el ermitaño eran más valiosos que el oro y la plata de las minas americanas.

A lo largo del siglo XVIII el santuario construido por el padre De la Cadena se enriqueció con nuevas construcciones y obras de arte y la afluencia de peregrinos desde todas las regiones de Nueva España se hizo mayor..$^{40}$ Varias ermitas fueron abiertas a su alrededor, además de la cueva, y en dos de ellas (la de la Inmaculada y la de Guadalupe), se admiraban sendas estatuas de los ermitaños mestizos "puestos de rodillas y con aparatos de penitencia". ${ }^{41}$ La rareza de la obra de Florencia, editada en Cádiz y escasamente conocida en México, y el crecimiento de la devoción hicieron necesario un texto más accesible, por lo que fray Juan de Magallanes, que fue prior del convento a principios del siglo XVIII (1720-1729) imprimió un breve compendio (14 folios) sobre la aparición y una novena, ambos textos varias veces reimpresos, pero en los que la presencia de los ermitaños mestizos había desaparecido. ${ }^{42}$ Fray Juan concluía con estas obras una

39 Antonio Rubial: La santidad controvertida. Hagiografía y conciencia criolla alrededor de los venerables no canonizados de Nueva España, México, FCE-Facultad de Filosofía y Letras, UNAM, 1999, p. 93.

40 Gonzalo Obregón: "El real convento y santuario de San Miguel de Chalma" en Homenaje a Silvio Zavala, México, El Colegio de México (Estudios Históricos Americanos), 1953.

41 Sardo: Relación histórica..., Lib. I, cap. XI, p. 97.

42 Juan de Magallanes: Aparición de la milagrosa imagen del Santo Christo que se venera en el religioso convento, y santuario de religiosos ermitaños del Orden de N.P.S. Augustin de San Miguel de Chalma, México, Biblioteca Mexicana de Joseph de Jáuregui, 1750. Esta es una reimpresión del original de 1731. Después de ella hubo varias ediciones (1778, 1792, 1799, 1816, 1839), a pesar de lo cual la obra es sumamente difícil de conseguir en la actualidad. La Universidad de Austin en Texas tiene un ejemplar. Magallanes también publicó un novenario para el Santo Cristo: Novena de la milagrosa imagen del Santo Christo que se venera en el religioso Convento y Santuario de Religiosos Ermitanos de la Orden de N.P. San Augustin de San Miguel de Chalma. México, Joseph de Jáuregui, 1778, con reediciones en 1783, 1788 y 1808. 
ardua labor a favor del santuario que gracias a sus trabajos fue remodelado y trasformado en un importante centro de vida religiosa. ${ }^{43}$

Finalmente, en 1810, otro prior de Chalma, fray Joaquín Sardo, publicaría una nueva historia del Santo Cristo copiando casi textualmente la obra de Florencia. En la dedicatoria a la provincia agustina, este autor insiste en la gran afluencia de peregrinos que iban a visitar la imagen a lo largo del año y recapitula la importancia que tuvieron los ermitaños en su difusión y culto. ${ }^{44}$ Para entonces Chalma era ya un santuario muy visitado, como lo sigue siendo hasta nuestros días, pero pocos de sus peregrinos recuerdan la historia de sus fundadores, los anacoretas mestizos.

\section{Dos Cristos expropiados con dos ermitaños apropiados. Totolapan e Ixmiquilpan}

Chalma y Sacromonte constituyen dos ejemplos de santuarios donde la imagen cristiana sustituyó a una antigua deidad indígena. Muy distintos son los casos de los Cristos de Totolapan e Ixmiquilpan, en los cuales también la sacralidad se conformó a partir del binomio imagen-ermitaño en pueblos de indios, pero su lugar de culto fueron templos de la ciudad de México a causa de un acto de expropiación realizada por autoridades eclesiásticas.

En el primer caso, el Señor de Totolapan, la imagen estuvo asociada desde su "aparición" con el misionero y ermitaño agustino fray Antonio de Roa, famoso por su violento ascetismo y por su labor en la Sierra Alta y en los conventos del área de Oaxtepec. En contraste con el silencio que Grijalva guarda sobre el milagroso Cristo de Chalma, la primera narración del prodigio del de Totolapan se la debemos a su pluma y a su crónica. Un día del año de 1543, narra el cronista, el padre Roa recibió en la portería del convento a un indio que le entregó un Cristo envuelto en una sábana. Fray Antonio, que deseaba que el pueblo poseyera una imagen similar al santo Cristo de Burgos, comenzó a hacerle las reverencias apropiadas y cuando quiso buscar al indio éste había desaparecido, por lo que se supuso que el portador no era humano sino un ángel. ${ }^{45}$

43 Alipio Ruiz Zavala: Historia de la provincia agustiniana del Santísimo Nombre de Jesús de Mexico, 2 vols., México, Porrúa, 1984, vol. II, p. 540.

44 Sardo: Relación histórica..., Dedicatoria. (Hay edición facsimilar, México, Gobierno del Estado de México (Biblioteca Enciclopédica del Estado de México, 80), 1979.

45 Grijalva: Crónica..., Lib. II, cap. 22, pp. 225-226. 
Javier Otaola, quien ha estudiado este caso, atribuye esta primera manifestación a una serie de hechos: los agustinos habían fundado su convento de San Guillermo en Totolapan en 1535 y al año siguiente a él se acogían los frailes expulsados de Ocuituco por el obispo Zumárraga, encomendero del pueblo, quien tenía con ellos un pleito por los excesivos trabajos a los que obligaban a sus indios. En ese ambiente de conflicto, y como una forma de afianzar su presencia en la zona, los agustinos iniciaron el culto a un Cristo crucificado alrededor de 1540. Por otro lado, apenas unos años atrás, en 1532, Totolapan había sido reconocida como cabecera independiente con un corregidor, frente a las pretensiones de Hernán Cortés de unirlo a Oaxtepec, que formaba parte de su marquesado. El milagroso Cristo daba también al pueblo un signo de identidad paralela a esa autonomía política recién adquirida. ${ }^{46}$

Cuarenta años estuvo el Cristo en San Guillermo Totolapan hasta que en 1583 los agustinos decidieron trasladarlo al recién fundado colegio agustino de San Pablo en la ciudad de México. El pretexto, una epidemia que comenzó en 1581 en la capital, causando en dos años la muerte de 24 religiosos agustinos; el objetivo real, dotar de una imagen milagrosa al Colegio de San Pablo de la capital, recientemente fundado e instalado como parroquia de indios contra la voluntad del arzobispo Pedro Moya de Contreras. La recepción del nuevo Cristo fue suntuosa y el cronista Chimalpáhin señala que "salieron a recibirlo al matadero de Xoloco los religiosos de las diversas órdenes", añadiendo que poco después lo trasladaron desde San Pablo a la iglesia de San Agustín "donde actualmente se encuentra". ${ }^{47}$

Los agustinos de la capital, interesados en dotar a su nuevo colegio de una imagen prestigiosa, comenzaron a promover el culto al Cristo divulgando varios de sus milagros, entre otros, su crecimiento inusual en la Cuaresma, sus sudoraciones, la "grandísima luz y blancura" que lo rodeaba, la curación de una viuda que padecía de hidropesía, asmas y flujo de sangre. Todo esto atrajo la atención de la Inquisición, posiblemente enviada por el arzobispo de México, y las averiguaciones comenzaron en la ciudad de México y en Totolapan. De ellas surgió el "Expediente del Santo Cristo de Totolapan y milagros que los frailes agustinos les imponían". ${ }^{48} \mathrm{En}$ él, a los testimonios de los milagros del Cristo, se aunaron aquellos sobre

46 Javier Otaola: "El caso del Cristo de Totolapan. Interpretaciones y reinterpretaciones de un milagro", Estudios de Historia Novohispana, 38, México, enero-junio 2008, pp. 19-38.

47 Chimalpáhin: Séptima Relación, vol. II, p. 257.

48 AGNM, Inquisición, v. 202, exp. 7, año de 1583. 
la vida penitente de Antonio de Roa, sobre las costumbres del culto local al Cristo y de la hermandad que se formó alrededor de la imagen.

Uno de los declarantes en el expediente, Domingo de Tolentino, indio de 76 años y que había sido gobernador de Totolapan cuarenta años atrás, aseguró que él había estado presente en la portería del convento cuando "un indio mozo, vestido con vestiduras blancas y muy hermoso de rostro", trajo el crucifijo y lo entregó al padre Roa. Así, utilizando la versión oficial de los agustinos, Domingo se insertaba como testigo presencial del milagro. ${ }^{49}$

Mientras tanto, en la capital el culto al santo Cristo de Totolapan iba en aumento y los agustinos decidieron trasladarlo a la iglesia de San Agustín, anexa a su convento matriz de Ciudad de México, como ya hemos indicado; curiosamente habían sido llevados allí los restos del "ermitaño" fray Antonio de Roa, muerto también en 1583. Sin embargo, la asociación entre el culto al Cristo y el cuerpo del ermitaño no se dio en ese momento, sino hasta el siglo XVIII, labor que correspondió a fray Manuel González de la Paz.

Este fraile peninsular, cronista de la provincia agustina de México, escribía en 1735 una biografía de fray Antonio de Roa, en la que incluía de nuevo la narración milagrosa del Cristo de Totolapan. Aquel año, la imagen había sido sacada en procesión para aplacar una epidemia y ante el éxito de la propuesta fray Manuel intentó promocionar el recuerdo de fray Antonio con esta biografía, que por otro lado jamás salió a la luz. En esta obra, el cronista señaló por primera vez la fuerte discusión que la comunidad indígena tuvo con los frailes a raíz del traslado en 1583, mencionando que los caciques y principales se amotinaron para impedir tal despojo y consiguieron que al menos se les dejara la cruz original donde estaba clavada la imagen; alrededor del culto a esta reliquia se fundó una cofradía dedicada a ella. ${ }^{50}$ Por extraño que parezca, este tema no había sido tocado ni en los testimonios de Totolapan, ni en la narración del cronista Grijalva.

Cinco años después de escribir la vida de Roa, en 1740, fray Manuel González intentaba promover la exhumación de sus restos mortales con el fin de colocarlos en un lugar prominente del templo para su veneración.

49 Otaola, "El caso del Cristo de Totolapan...", p. 30.

50 Manuel González de la Paz: Monstruo de la penitencia. Parto feliz del monstruo de la Gracia. Portentosa, inimitable, cruel Vida del Venerable, Austero, Rigidísimo, Penitente Varón Fray Antonio de Roa. 1735. Manuscrito. Archivo Histórico de la Biblioteca Nacional de Antropología e Historia, Colección Antigua, no. 893, fs. 54-58. 
También en esto fracasaron sus intentos, a pesar de que entre 1750 y 1754 , como prior de México, hizo colocar una placa destacando la tumba de Roa. ${ }^{51}$

En 1758 fray Manuel era elegido prior de San Guillermo Totolapan y posiblemente fue durante su estancia cuando se mandaron pintar a Francisco Vallejo los dos lienzos que se encuentran en el sotocoro de la iglesia de ese pueblo. En uno aparece el insigne misionero fray Antonio de Roa con el torso desnudo, cargando una cruz sobre sus hombros y con unos leños ardientes bajo sus pies. En el otro lienzo, el mismo Roa recibe de manos de un ángel el santo Cristo cuya cruz era venerada en la comunidad como una singular reliquia, pero cuyo cuerpo se encontraba en la iglesia de los agustinos de la capital. Curiosamente esta escena se encuentra en un segundo plano, pues el primero lo ocupa la imagen admirada por cuatro agustinos. Ante los fracasos en la promoción de su valorado Roa en la capital, fray Manuel intentó por este medio mantener su memoria en el pueblo donde había recibido tan gran favor celestial.

A principios del siglo XVII se trasladaba a la capital otro Cristo milagroso del ámbito indígena: el señor de Ixmiquilpan. La imagen había sido llevada a Mapeté (o el Cardonal), un poblado minero dependiente del convento agustino de Ixmiquilpan, por el español Alonso de Villaseca en 1545 y fue colocada en una modesta capilla sin que nadie se ocupara de ella. ${ }^{52} \mathrm{La}$ primera noticia de un milagro realizado por esta imagen y de su traslado a la ciudad de México la da el cronista Gil González Dávila en su Teatro eclesiástico (publicado en Madrid en 1649) al final de la vida del arzobispo Juan Pérez de la Serna:

En el lugar de las minas de Ixmiquilpan en 17 del mes de febrero del año de 1621, una imagen de bulto de Cristo crucificado, que estaba en la iglesia de ese lugar, que es vicaría de padres de San Agustín, sudó tres veces con un sudor muy copioso. Y más adelante por el mes de julio [...] se estremeció en la cruz a la vista de mucha gente [...] El arzobispo [Pérez de la Serna] formó proceso del caso y de los muchos milagros que Dios ha obrado por ella, y trasladó la santa imagen de donde estaba, que es tierra de chichimecos, y la colocó en el convento del Ángel de la guarda de la ciudad de México. ${ }^{53}$

51 Víctor Ballesteros García: La crónica de fray Manuel González de la Paz de la orden de San Agustín, México DF, Facultad de Filosofía y Letras, UNAM, Tesis inédita de Doctorado en Historia, 1997.

52 William Taylor: "Two Shrines of the Cristo Renovado: Religion and Peasant Politics in Late Colonial Mexico", The American Historical Review, 110-4, october 2005, 50 pars. http://www.historycooperative.org/journals/ahr/110.4/taylor.html.

53 Gil González Dávila: Teatro eclesiástico de la primitiva Iglesia de la Nueva España en las Indias occidentales. Edición facsimilar de Edmundo O Gorman, México, Centro de Estudios de Historia de México Condumex, 1982, p. 59. 
González Dávila, quien jamás visitó América, ignoraba que el monasterio donde fue depositado el Santo Cristo no era el del Santo Ángel, sino el de San José de las carmelitas descalzas fundado en $1615 .{ }^{54}$ Páginas atrás, el mismo autor señalaba que en 1616 (cinco años antes del traslado), el capellán de ese monasterio, Francisco de Losa, había colocado en la iglesia recién fundada y promovida por el arzobispo Juan Pérez de la Serna, el cuerpo del ermitaño Gregorio López. Este personaje, famoso por su sabiduría y ascetismo, murió en olor de santidad en el vecino pueblo de Santa Fe y Losa, que escribiría una biografía de él años después, había sustraído en secreto su cadáver quince días antes de la dedicación de la iglesia de San José, con la anuencia del arzobispo. ${ }^{55} \mathrm{Al}$ igual que el Cristo que llegaría después, esta reliquia del ermitaño muerto expropiada a los indios, se convertía en un importante elemento para reforzar la sacralidad del nuevo templo y el prestigio de su fundador el arzobispo. Aunque la reliquia estuvo poco tiempo en ese recinto pues el arzobispo Francisco Manzo y Zúñiga, promotor de la causa de beatificación de Gregorio López, dejó la orden de trasladar las reliquias del ermitaño a la catedral de México (lo que sucedió en 1636), un espacio de mayor jerarquía para quien se esperaba fuera en breve un santo elevado a los altares. ${ }^{56}$ El mismo prelado había ordenado también construir en 1634 una capilla para el santo Cristo, que hasta entonces había estado detrás del altar mayor de la iglesia, en el espacio de clausura de las monjas, aunque visible para los fieles a través de una reja.

Muy posiblemente alrededor de esta separación entre imagen y reliquia, se comenzó a elaborar una leyenda mucho más compleja sobre el Santo Cristo de Ixmiquilpan, que aquella recogida por González Dávila según la cual la imagen sólo había sudado y temblado. Alonso Alberto Velasco (1635-1704), autor criollo y capellán también de dicho convento de monjas, fijó el texto canónico de esa segunda leyenda sobre la aparición, que fue publicado en 1688 en su primera versión bajo el título Renovación por si misma de la soberana imagen de Cristo Señor Nuestro crucificado

54 Autores posteriores, como Alonso Alberto de Velasco, señalan que el arzobispo llevó primero el Cristo a su capilla doméstica en el palacio episcopal y que su donación al convento de las carmelitas no se hizo en 1621 sino hasta 1626, cuando el prelado dejó la sede para trasladarse a Castilla.

55 Mariana de la Encarnación: Crónica del convento de las carmelitas descalzas de la ciudad de México. 1641, publicado por Manuel Ramos Medina en: Místicas y descalzas, México, Centro de Estudios de Historia de México Condumex, 1997, pp. 357-358.

56 Antonio Rubial: La santidad controvertida, p. 107. 
que llaman de Itzmiquilpan. ${ }^{57}$ En esta narración, el capellán recoge las noticias anteriores sobre la imagen, intenta explicar sus inconsistencias, recopila los "instrumentos" y testimonios sobre la prodigiosa renovación y sobre los milagros que ha realizado, reúne los pareceres solicitados a los artistas y ensambladores sobre la imagen y da una versión ordenada de los hechos. Velasco insiste en esta primera redacción en el papel que tuvo la presencia de las reliquias de Gregorio López cuando se colocó cerca de ellas la imagen en el convento de las carmelitas. Remarca este vínculo al señalar que el epitafio que se había colocado en la caja de las reliquias se mantuvo cerca de la imagen aún después del traslado del cuerpo del ermitaño a la catedral en $1636 .{ }^{58}$ López, sin embargo, forma una parte accesoria que Velasco utiliza para resaltar las principales cualidades del Cristo, "Exceder al arte y tener muchos milagros". Ellas sirven como argumento central de un texto redactado como un "informe" que formará parte de la gran promoción que el arzobispo Francisco Aguiar y Seixas estaba dando a la imagen. Al igual que sucedió en sus inicios, el episcopado tomaba de nuevo bajo su protección el culto. En septiembre de 1684 el prelado bendecía el nuevo templo de las carmelitas construido con el apoyo del rico mercader Molina Mosqueira, y colocaba al Santo Cristo en una nueva capilla fabricada ex profeso para él. Tiempo después, en 1689, al año siguiente de la aparición del texto de Velasco, el arzobispo reunía una junta arzobispal que declaraba "por milagro" la renovación del Santo Cristo de Santa Teresa. ${ }^{59}$

El gran impulso de la promoción episcopal continuó después de la muerte del arzobispo. Una nueva versión de la narración de Velasco, revisada para un público más amplio, aparecía impresa en 1699, acompañada con oraciones y novenarios y con un nuevo título: Exaltación de la Divina Misericordia. En la obra se construía alrededor de esa imagen un complejo escrito lleno de alusiones morales y alegorías históricas en el que la presencia indígena era incidental. En la nueva narración el autor señalaba que la imagen estaba tan carcomida por la polilla y la humedad que en 1615 el "arzobispo" había ordenado que en lugar de destruirla fuera enterrada con el primer adulto que muriera en la parroquia. Durante cerca de seis años

57 Alonso Alberto de Velasco: Renovación por si misma de la soberana imagen de Cristo Señor Nuestro crucificado que llaman de Itzmiquilpan. México, Viuda de Rodríguez Lupercio, 1688. Sobre Gregorio López, ver Rubial: La santidad controvertida, pp. 107-120.

58 Velasco, Renovación..., fs. 30r., 79vto.-80vto. El autor también insiste en el papel que tuvo Francisco Losa en el culto a Gregorio López.

59 Robles: Diario..., vol. II, pp. 74 y 181. 
nadie murió, pero todo ese tiempo una música celestial salía de la capilla por las noches. Ese fue el inicio de la milagrosa renovación que iba acompañada con todo un aparato de gritos desgarradores, de sudor, de sangre, de emisiones de luz y de movimientos de ojos y de boca. La descripción sirve para hacer un discurso retórico sobre los sufrimientos del Calvario.

A continuación se hace narración del traslado, precedido por un motín popular que se oponía a él y sucedido por una procesión devota y curativa, y su llegada al templo de las carmelitas. El resto del libro es una meditación sobre el alma (afeada por el pecado y restituida con los dones del Espíritu Santo a la belleza y candidez de la infancia) y adecuación de los hechos históricos que vivió la ciudad en el siglo XVII para convertirlos en una manifestación alegórica de los milagros que rodearon a la renovación de la imagen. La expulsión del arzobispo por el virrey durante la rebelión popular de 1624 significaba un ataque a los fueros eclesiásticos, que triunfaron finalmente con la restitución arzobispal. Las pocas muertes acaecidas durante la inundación de 1629, la persecución contra los judíos y su quema en la hoguera en la capital en 1649 eran hechos interpretados a la luz de una imagen que con sus prodigios enseñaba, purificaba y aliviaba a la ciudad de todas las plagas.

Una parte importante del discurso de Velasco se centraba en la colocación previa de los huesos del ermitaño Gregorio López en el templo de las carmelitas. Este "fénix o gigante entre los muy espirituales y perfectos", se convierte en un prototipo de vida para las religiosas. Su presencia al lado de la imagen se debe "a la gloria tan alta y eminente lugar que goza su alma en el cielo", hecho que le fue revelado por el mismo Cristo a sor Mariana de la Cruz, una de las fundadoras del Carmelo mexicano, con estas palabras: "¿por qué piensas que Gregorio tiene su asiento y cabe mi? Porque dejó todas las cosas temporales por mi y se retiró dentro de sí en silencio". ${ }^{60}$

A pesar de que el ermitaño ya no estaba en el templo, las referencias seguían haciéndolo parte de la leyenda de la imagen y una de las glorias de la capital. No es gratuito que el mismo Velasco fuera asiduo promotor de la canonización de Gregorio López, y que en 1690, ya cura del sagrario

60 Alonso Alberto de Velasco: Exaltación de la Divina Misericordia en la milagrosa renovacion de la soberana Imagen de Christo Señor N. Crucificado que se venera en la Iglesia del Convento de San Ioseph de Carmelitas Descalzas de esta ciudad de México, México, María de Benavides Viuda de Ribera, 1699, p. 48. Este autor toma la cita de esta revelación de Carlos de Sigüenza y Góngora: Paraíso Occidental, México, Juan de Ribera Impresor, 1683. Edición moderna de Margo Glanz, en México, Condumex-UNAM, 1995, Lib. II, cap. XIX, p. 99r. 
metropolitano, estuviera encargado de recoger las limosnas para su causa en Roma e impulsara las obras de la ermita de Santa Fe, donde el venerable había pasado sus últimos años. ${ }^{61}$

El gran éxito del nuevo libro de Velasco provocaba que en 1724 se realizara una reimpresión, promovida por las religiosas carmelitas, y en 1737 salía a la luz una novena para el uso de los devotos de la imagen escrita por el jesuita Domingo de Quiroga. ${ }^{62}$ Nuevas ediciones del texto de Velasco en 1776, 1790, 1807, 1810 y 1820, alimentadas por la necesidad de los devotos, y varias más de la novena de Quiroga, son una muestra de la gran popularidad que tuvo el culto en la capital. Entre 1724 y 1776 William Taylor ha constatado numerosas manifestaciones de fervor hacia la imagen, considerada "celestial médico", objeto de novenarios públicos y procesiones a la catedral para solicitar alivio en las epidemias. ${ }^{63}$

Paralelamente a este impulso, en el siglo XVIII se produjo una insólita promoción del culto en el mismo espacio donde se había llevado a cabo la milagrosa renovación: Mapeté. Al parecer, con motivo de la edición de la obra de Velasco en 1724, varios caciques otomíes de la zona minera de Zimapán, El Cardonal y Plomo Pobre se disputaron el control del lugar del prodigio, cuya capilla estuvo abandonada hasta 1720, pero que desde 1728 comenzó a reconstruirse con una suntuosa iglesia (concluida en 1765) y a atraer a numerosos peregrinos indígenas, mestizos y españoles. La recolección de limosnas se volvió un tema central de los conflictos entre los diferentes promotores del nuevo santuario, que se llenó de diversas imágenes de Cristo que copiaban la original. Lo notable del nuevo santuario, como lo ha mostrado William Taylor, no eran las imágenes veneradas en él, sino el hecho de que el espacio sagrado donde aconteció el primer milagro había adquirido por sí mismo una importancia insólita, como lo manifestaban las curaciones y prodigios que en él seguían sucediendo. Gracias a las redes que las comunidades otomíes tenían en un extenso territorio que llegaba hasta Querétaro, el Bajío, Tlaxcala y Michoacán, el culto a este Santo Cristo (al igual que sucedió con el de Chalma como vimos) adquirió una territorialidad inusitada. ${ }^{64}$ A pesar de que existía la esperanza, alimentada

61 Rubial: La santidad controvertida, p. 119.

62 Domingo de Quiroga: Novena de la milagrosa imagen del Santo Crucifixo que se venera en el Convento Antiguo de Señoras Carmelitas Descalzas de la imperial Ciudad de México, México, María de Rivera, 1737.

63 Taylor: "Two Shrines...", p. 10.

64 Ibidem, pp. 16-19. 
por la obra de Velasco, de que el Santo Cristo que se veneraba en la capital regresara a Mapeté, su lugar de origen, cuando se concluyera un santuario digno de él, esto nunca sucedió. Sin embargo durante la Cuaresma, la procesión de los Cristos, que llegaban de los alrededores de la zona minera, convirtió a Mapeté en uno de los más importantes centros de culto de México.

Lo que nunca sucedió con el Cristo de Ixmiquilpan pasó con el de Totolapan. En 1861, a raíz de la exclaustración de los agustinos, la comunidad de Totolapa recuperó su imagen y alrededor de ella se siguieron tejiendo numerosos milagros. En ambos casos la memoria indígena se había conservado alrededor de la imagen milagrosa a pesar de su expropiación y esa persistencia de la memoria permitió a la larga la recuperación del objeto sagrado, pero en ninguno de los dos casos tuvo continuidad el papel impulsador que tuvieron los ermitaños en sus orígenes.

\section{Vírgenes viajeras poblanas y ermitaños europeos. Las imágenes de La Defensa y La Guía.}

William Taylor ha calculado que existen en México alrededor de 480 santuarios con imágenes milagrosas, de los cuales 261 están dedicados a imágenes de Cristo y 219 a la Virgen María ${ }^{65}$ Entre estos últimos son notables aquellos que, como los del Tepeyac y Los Remedios, sirvieron para sustituir a antiguas diosas madres. Otros, en cambio, fueron utilizados para reforzar los sentimientos de identidad patria en las diferentes ciudades del territorio. En el Zodiaco mariano, obra escrita entre 1679 y 1750 por los jesuitas Francisco de Florencia y Juan Antonio de Oviedo, se recopilaron 106 narraciones sobre imágenes milagrosas de los santuarios locales novohispanos dedicados a la Virgen María. ${ }^{66}$ Entre ellas se distingue una que está vinculada con la zona de Puebla Tlaxcala y en la que es notable la presencia de un ermitaño: la Virgen de la Defensa, asociada muy directamente con Juan Bautista de Jesús.

Las noticias del hecho fueron dadas a la luz en 1683 por Pedro Salgado Somoza, confesor del ermitaño que era natural de Toledo y que

65 Ibidem, p. 2.

66 Zodiaco Mariano, México, Imprenta del Colegio de San Ildefonso, 1755. (Edición moderna de Antonio Rubial, México, CONACULTA, 1995). 
vivió en los bosques de Tepeaca entre 1621 y 1660. El autor criollo no sólo había ordenado a Juan Bautista poner por escrito las maravillas obradas por la imagen que tenía en su poder, sino también fue él quien llevó estos informes a Juan de Palafox, personaje que jugó un importante papel en la promoción del culto. ${ }^{67}$ En la obra de Salgado, el obispo de Puebla aparece como un prelado celoso y devoto que "despachó un auto que mandaba se hiciese información jurídica de muchas de las cosas que en el escrito se contenían" y mandó traer la imagen a su palacio mientras se le disponía un altar en la catedral. Pero antes de que esto sucediera, señala el mismo autor, la Virgen fue entregada por Palafox al almirante Pedro Porter Casanate para que lo acompañara en una expedición a California, en la cual lo libró de numerosos peligros; este personaje se la llevó después a Chile, donde participó en las campañas contra los araucanos. En 1676 la imagen regresó a Nueva España gracias a la intermediación de los jesuitas y fue colocada por el deán y Cabildo en el altar de los Reyes de la catedral de Puebla, después de una apoteósica recepción que le hizo la ciudad. ${ }^{68}$

La segunda parte de la obra de Salgado contiene un epítome con la vida del venerable ermitaño. En él aparece como un personaje libre de toda herejía, aclaración necesaria por la abundancia de falsos eremitas insumisos y engañadores, cuya ortodoxia quedó avalada por una junta de teólogos que lo examinó por orden de Palafox. A continuación Salgado describe una vida llena de prodigios: luchas con las fuerzas demoníacas (que lo golpeaban y arrastraban por las cañadas y lo mordían para impedir que escribiera los milagros de la Virgen); practicas de un ascetismo sobrehumano que lo convirtieron en un hombre salvaje "negro, flaco, con el cabello descompuesto erizado y lleno de hojas"; y sorprendentes portentos (calaveras parlantes, águilas portadoras de pan, crucifijos que aparecían y desaparecían). Pero lo más importante era que su vida estuvo entregada al culto y veneración de la Virgen de la Defensa y de una copia de la imagen que él había mandado hacer cuando Palafox se llevó la original a Puebla. ${ }^{69}$

Francisco de Florencia, quien años después reunió las narraciones de Salgado y de Juan Bautista, dio una versión completa de los prodigios de

67 Pedro Salgado Somoza: Breve noticia de la devotísima imagen de Nuestra Señora de la Defensa... Con un epítome de la vida del venerable anacoreta Juan Bautista de Jesús, Puebla, Diego Fernández de León, 1683 (hay una reedición en Puebla en 1760).

68 Ibidem. El hecho se explica por el parentesco que el almirante tenía con la madre del obispo Ana de Casanate, aunque los hagiógrafos sólo señalan que era compatriota de Palafox.

69 Ibidem, pp. 30-33. 
la imagen en su Zodiaco mariano. En ella la Virgen aparece como protectora de aves y roedores que huyen de los depredadores y se refugian en la ermita, la acompañaban continuamente luz y música de ángeles y los demonios sollozaban en los árboles por las almas que se salvaban por su intermediación. Los mismos milagros se continuaron con la copia que el ermitaño mandó fabricar para sustituir a la que se llevaran Palafox y Casanate; ésta protegía a los animales que entraban en la ermita, detuvo destructoras tempestades y viajó a la cabecera de los enfermos para traerles alivio. ${ }^{70}$ Con Florencia se consolidaba un ciclo narrativo, quizás el más representativo, que vinculaba dos imágenes marianas con las actividades milagrosas de un ermitaño. Esta asociación tuvo una larga continuidad en el santuario que se construyó para albergar la segunda imagen de la Virgen de la Defensa, en el cual Juan Bautista estaba enterrado. En una remodelación de este espacio llevada a cabo en 1808 aún seguía presente la memoria de este personaje, como lo constatan dos lienzos que describen su vida y que se mandaron pintar en la ermita. Las pinturas llevan numerosas inscripciones sacadas de la obra de Salgado Somoza. ${ }^{71}$

El último caso que voy a tratar pertenece también al área de Tlaxcala, lugar al parecer muy solicitado por los eremitas. De él sólo se conserva una breve narración contenida en una oración panegírica, editada en 1657 y predicada a raíz de la traslación de las cenizas del ermitaño Diego de los Santos Lijero a la parroquia de Tlaxcala. El autor del sermón, Antonio González Lasso, describía la vida del anacoreta que se retiró a las soledades después de llevar una vida disipada. Cuenta su biógrafo que en una de sus aventuras galantes, la hermosa joven que el esperaba encontrar se transformó en un ser demoníaco con ojos de fuego y cabellos de serpiente, experiencia que lo llevó a una profunda conversión. Después de un año y medio de retiro en el yermo, Diego se fue a Filipinas con el deseo de pasar al Japón a entregar su vida por la fe; y aunque tal deseo no le fue concedido, en Manila consiguió algo muy preciado: la imagen milagrosa que lo hizo famoso a su regreso a la Nueva España, la Virgen de la Guía. Al morir el ermitaño en 1648, la imagen pasó a la parroquia de Tlaxcala y nueve años después las cenizas del ermitaño, fundador de dos cofradías y el mismo hermano de la congregación de San Pedro, eran colocadas a los pies de la Virgen que él mismo había traído del Oriente y junto a la cual quiso estar

70 Florencia y Oviedo, Zodiaco mariano, pp. 217-220.

71 Jaime Cuadriello: "Tierra de prodigios. La ventura como destino", pp. 212-214. 
sepultado. ${ }^{72}$ Es por tanto el único caso en el que el cuerpo del ermitaño fue de nuevo vinculado con su imagen asociada.

Al parecer ni la imagen ni el ermitaño tuvieron una importancia destacada en el ámbito tlaxcalteca. El Zodiaco mariano no los menciona y no encontramos ninguna otra noticia de ellos en otras fuentes. Es muy probable que la presencia de santuarios de primera magnitud (la Virgen de Ocotlán y San Miguel en Nativitas), cohesionadores de la identidad tlaxcalteca, impidieran el desarrollo extensivo de cultos menores como el de la Virgen de la Guía, que se volvió una más entre las varias que poseía la parroquia.

\section{Epílogo}

A lo largo de los ejemplos aquí estudiados se puede observar cómo los ermitaños, y sobre todo sus cuerpos tratados como reliquia, sirvieron para reforzar la sacralidad de las imágenes milagrosas. En todos los casos, sus cadáveres (u objetos asociados) fueron enterrados cerca de ellas en algún momento de la evolución del culto. En varios de ellos (Chalma, Ixmiquilpan, la Guía) se dio además el fenómeno contrario, es decir que el cuerpo del ermitaño fuera retirado de su cercanía con la imagen. Es también significativo que, salvo en aquellas que generaron santuarios (Chalma y Sacromonte), las imágenes, al igual que los cuerpos de los ermitaños, llegaron de fuera. Esto pasó sobre todo en aquellas que se anexaron a capillas en templos ya construidos para reforzar su prestigio (San Francisco y la catedral de Puebla, la parroquia de Tlaxcala, la iglesia de San Agustín y el templo de las carmelitas descalzas de la capital).

Es también muy significativo que en varios de los casos aquí estudiados se diera un fenómeno de expropiación del icono por parte de un núcleo urbano: la Virgen Conquistadora y la de la Defensa por parte de Puebla y la Virgen de la Guía por Tlaxcala, los Cristos de Totolapan e Ixmiquilpan por la capital. Este carácter de objeto "robado" está presente también en algunas de las narraciones relacionadas con los cuerpos de los ermitaños.

El impacto de estos personajes fue tan amplio que algunas otras narraciones se vieron influidas por ellos. Juan Diego, el vidente de la Virgen de Guadalupe, terminó, según la versión del jesuita Florencia, como ermitaño

72 Antonio González Lasso: Oración panegyrica que en la traslación de las cenizas del venerable varón Diego de los Santos Ligero, heremita en los desiertos de la ciudad de Tlaxcala... oró el licenciado... Puebla, Viuda de Juan de Borja, 1657. 
en la capilla construida para custodiar la imagen milagrosamente aparecida. En otros casos, la misma promoción de una imagen en una ermita se convertía en motivo para que su cuidador tomara el carácter de ermitaño. Un ejemplo de ello fue la Virgen de Tulantongo, cercana a Tezcoco, promovida por Antón de Candía, un mestizo ciego fingido y mendigo. Entre 1628 y 1642 este personaje comenzó a difundir que un lienzo de la Virgen que poseía le había devuelto la vista y con las limosnas que recogió le fabricó a la imagen una ermita que pronto se convirtió en santuario de peregrinación. A su alrededor el ermitaño había construido un obraje textil, una panadería y una tocinería donde trabajaban varios indios e indias y tenía ovejas, carneros, bueyes y una recua de mulas. A pesar de haber sido acusado ante la Inquisición en 1656 por "usurpador de la eclesiástica jurisdicción y sagrada dignidad del sacerdocio", pues imponía "la ceniza a los indios el día que para esa sagrada ceremonia tiene señalado la iglesia; bendice a los indios públicamente, y a los que van a visitar a la Virgen y pedirle socorro en algunas necesidades, les da él las respuestas en nombre de la imagen santísima". ${ }^{73}$ El tribunal determinó que el ermitaño debía dar cuenta de las limosnas cada seis meses al guardián del convento franciscano de Texcoco. Esto motivó que muy pronto la ermita pasara al control de los frailes, quienes en 1676 fabricaban una nueva iglesia en ese espacio a expensas de Melchor de Peralta. Fray Agustín de Vetancurt, quien da esta última noticia, señala que en Tulantongo había un religioso bajo la obediencia del padre guardián de Texcoco, pero ya no hace referencia al ermitaño ciego y sólo menciona la capilla adscrita a su orden en la que se veneraba la imagen de la Inmaculada Concepción. ${ }^{74}$

Aquí, como hemos visto en otras imágenes, las autoridades religiosas tendieron a separar ermitaños de imágenes, quizás porque aquellos comenzaron considerarse peligrosos por su carácter autónomo y a veces contestatario. Sin embargo, por el carácter milagroso con el que estaban revestidos ambos y por la gran fuerza que tenían en el imaginario los temas de la santidad y de los íconos milagrosos, no es gratuito que el binomio ermitañoimagen cumpliera importantes funciones simbólicas en el imaginario novohispano desde el siglo XVI hasta bien entrado el siglo XIX.

Recibido el 4 de febrero de 2009 Aceptado el 29 de septiembre de 2009

73 AGNM, Indios, v. 20, fs. 151r. y vto.

74 Agustín de Vetancurt: Teatro mexicano. Crónica de la provincia del Santo Evangelio, México, María de Benavides Viuda de Ribera, 1698, p. 89. 